\title{
The Effect of Type 2 Diabetes Mellitus on the Development of Alzheimer's Disease and Its Molecular Mechanism
}

\section{Tip 2 Diabetes Mellitus'un Alzheimer Hastalığının Gelişimindeki Etkisi ve Moleküler Mekanizmaları}

\author{
(i) Rabia DURAN1, iD Sümeyra PANCUR², iD Fatemeh BAHADORI1
}

1Bezmialem Vakıf University Faculty of Pharmacy, Department of Pharmaceutical Biotechnology, İstanbul, Turkey

2İstanbul University Faculty of Pharmacy, İstanbul, Turkey

\begin{abstract}
Following increased epidemiological studies indicating the relationship between diabetes and Alzheimer's disease (AD), Type 2 diabetes has been reported to be a risk factor for the progress of $\mathrm{AD}$ pathology. Insulin resistance that develops in the brain, impairment in the insulin signal delivery system and glucose metabolism have been shown among the most likely pathophysiological causes of $\mathrm{AD}$. It has been reported that the increase in $\mathrm{AD}$ markers such as phospho tau and $\mathrm{A} \beta$ in the type 2 diabetes model of rats is associated with the decrease in the insulin receptor (IR) signaling and insulin-like growth factor-1 receptors (IGF-1R) ratio. Furthermore, intracellular components such as phospho-AKT (protein kinase B) and phospho-glycogen synthase kinase-3 $\beta$ (GSK3 $\beta$ ), which are members of IR pathway, have been proved to be reduced in $\mathrm{AD}$. Due to the common molecular mechanisms underlying the pathological development of Type 2 Diabetes and $\mathrm{AD}$, treatment protocols indicated in diabetes have been used in the treatment of $\mathrm{AD}$.
\end{abstract}

Keywords: Diabetes, Alzheimer's, IR, IGF-1R, p-AKT, GSK3 $\beta$, amyloid $\beta$, tau

\section{ÖZ}

Diyabet ve Alzheimer hastalığı (AH) arasındaki ilişkiyi işaret eden epidemiyolojik çalışmaların artmasının ardından, Tip 2 diyabetin AH patolojisinin oluşumunda bir risk faktörü olduğu bildirilmiştir. Beyinde gelişen insülin rezistansı, insülin sinyal iletim sisteminde ve glukoz metabolizmasında bozuklukların meydana gelmesi en olası patofizyolojik sebepler arasında gösterilmiştir. Tip 2 diyabet modeli sıçanlarda fosfo tau ve $A \beta$ gibi $\mathrm{AH}$ belirteçlerinin arttığı bununla beraber insülin reseptör (IR) sinyalinin ve insülin benzeri büyüme faktörü-1 reseptörlerinin (IGF-1R) azaldığı bildirilmiştir. Ayrıca AH'de insülin reseptör yolağında yer alan fosfo-AKT (protein kinaz B) ve fosfo-glikojen sentaz kinaz-3 $\beta$ (GSK3 $\beta$ ) gibi hücre içi bileşenlerinin azaldığı kanıtlanmıştır. Tip 2 diyabet ve AH'deki patolojik süreçlerin altında yatan ortak moleküler mekanizmalar nedeniyle, $\mathrm{AH}$ tedavisinde diyabette endike olan tedavi protokolleri kullanılmaya başlanmıştır.

Anahtar Sözcükler: Diyabet, Alzheimer, IR, IGF-1R, p-AKT, GSK3 $\beta$, amiloid $\beta$, tau

Address for Correspondence: Fatemeh BAHADORI, Bezmialem Vakıf University Faculty of Pharmacy, 


\section{Introduction}

The prolongation of life expectancy has led to an increase in the prevalence of dementia that develops with aging and the incidence of Alzheimer's disease (AD) as the predominant diagnosis. The incidence is low among individuals under the age of 70 , but the risk of $\mathrm{AD}$ doubles in individuals over the age of 70 every 5 years (1). However, the inability to effectively treat $\mathrm{AD}$ constitutes one of the most important health and socioeconomic problems in the world (2).

Alzheimer's disease is a progressive, neurodegenerative CNS disease characterized by deterioration of memory and cognitive functions (3). Pathologically, senile plaques with extracellular amyloid- $\beta(\mathrm{A} \beta)$ accumulation, and neurofibrillary tangles (NFTs) formed by hyperphosphorylation of tau protein in the cell are seen. Neuroinflammation, active gliosis, synaptic disorders and neuronal loss in the brain cause significant cerebral atrophy (4).

$\mathrm{AD}$ is categorized in two forms as familial (inherited) and sporadic (late onset). Although there are no similarities in the etiology of familial and sporadic $\mathrm{AD}$, the morphological endpoint in the brain and clinical picture occurring are the same (5). Of patients $5 \%$ have familial $\mathrm{AD}$ which is inherited by autosomal inheritance. Mutations in the amyloid precursor protein (APP) gene in the $21^{\text {st }}$ chromosome, the presenilin-1 gene in the $14^{\text {th }}$ chromosome and the presenilin-2 gene in the $1^{\text {st }}$ chromosome are held responsible for the development of familial AD. Sporadic AD, on the other hand, accounts for $90-95 \%$ of patients. Although the cause of the sporadic form is not known exactly, it is thought to occur as a result of interactions between environmental and genetic risk factors during the aging process (6).

Type 2 diabetes mellitus (T2DM) is the inability of body cells to fully respond to insulin, called "insulin resistance", and is a chronic metabolic disease characterized by hyperglycemia resulting from insufficient insulin secretion. Due to the decrease in the response of the cells to the hormone during insulin resistance, an increase in insulin production occurs over time. However, as a result of overworking pancreatic beta cells and the body's inability to keep up with the increasing insulin needs, insufficient amount of insulin is produced $(7,8)$.

Patients with T2DM constitute approximately $90-95 \%$ of all diabetic patients (9). According to the information in the guide published by the International Diabetes Federation (IDF) in 2019, there were 351.7 million people with diabetes between the ages of 20-64 who were diagnosed or undiagnosed in 2019. This number is expected to increase to 417.3 million in 2030 and to 486.1 million in 2045. T2DM usually occurs after the age of 30, but it has been increasingly seen in children and young adults due to reasons such as increasing obesity, physical inactivity and not eating a healthy and balanced diet $(7,8)$.

Patients with T2DM constitute approximately $90-95 \%$ of all diabetic patients (9). According to the information in the guide published by the IDF in 2019, there are 351.7 million people with diabetes between the ages of 20-64 who are diagnosed or undiagnosed in 2019. This number is expected to increase to
417.3 million in 2030 and to 486.1 million in 2045. T2DM usually occurs after the age of 30 , but it has been increasingly seen in children and young adults due to reasons such as increasing obesity, physical inactivity and not eating a healthy and balanced $\operatorname{diet}(7,8)$.

Following the increasing interest in the effects of T2DM on the brain in recent years, the number of studies investigating the relationship between these two diseases has also increased (10). However, a growing body of epidemiological and molecular knowledge demonstrates the existence of common risk factors, pathophysiological mechanisms and consequent comorbidities, which significantly encompass T2DM and AD.

Neuroimaging studies have revealed differences in brain structure and function in individuals with long-standing T2DM compared to healthy individuals. It has been found that cerebral atrophy is more common in the brain, especially in areas related to cognition, in elderly individuals with insulin resistance and diabetes compared to elderly individuals without insulin resistance or diabetes (11). Increasing epidemiological studies show that patients with T2DM have a higher risk of developing $\mathrm{AD}(9,12,13)$. According to a cohort study with 9 years of longitudinal follow-up, diabetic patients had a $65 \%$ higher risk of developing $\mathrm{AD}$ than non-diabetic controls. Cognitive dysfunction is now recognized as a complication of chronic T2DM, and T2DM is seen as an important risk factor for decreased performance in various neuropsychological areas (10). Ongoing clinical and epidemiological studies show that impaired metabolic parameters such as hyperglycemia and hyperinsulinemia are associated with decreased cognitive functions and the development of late-onset AD pathology (14).

In this study, it is aimed to focus on T2DM and related mechanisms that contribute to the development of sporadic $\mathrm{AD}$ pathology and play an important role in the clinical course of AD.

Possible Mechanisms Associated with Alzheimer's Disease and Type 2 Diabetes Mellitus

\section{Insulin and Insulin-Like Growth Factor 1 (IGF-1)}

$\mathrm{AD}$ is referred to as "Type 3 diabetes" in some references due to the repeated link between insulin and the mechanisms involved in $\mathrm{AD}$ pathology (15). First of all, it is known that insulin, which is accepted as a hormone effective in the periphery, has strong effects on the brain as well.

In the brain, insulin receptor (IR) density is highest in the olfactory bulb, hypothalamus, hippocampus, cerebral cortex, striatum, and cerebellum. Insulin levels in the cerebrospinal fluid (CSF) are much lower than in plasma, but these levels correlate with serum insulin levels, suggesting that most of the insulin in the brain originates from circulating pancreatic insulin (16).

Insulin, a peptide secreted by pancreatic beta cells, is transported across the blood brain barrier (BBB) to the central nervous system (CNS) by receptor-mediated saturation sensitive transport. Transition from BBB can be affected by a number of factors 
such as obesity, triglycerides, inflammation and hyperglycemia. Studies conducted on humans have reported that the CSF/ serum ratio of insulin decreases with insulin resistance, $\mathrm{AD}$, and increasing age $(11,15)$.

The detection of insulin mRNA transcripts in certain regions of the brain, especially in the hippocampus and hypothalamus, as a result of studies conducted in human post-mortem brain tissue suggests that insulin may also be produced in certain regions of the brain $(11,12)$. Studies on IR expression and receptor binding in humans compared patients with $\mathrm{AD}$ with age-matched controls and showed decreased expression of IR mRNA and protein in patients with $\mathrm{AD}$. The decrease in IR binding in $\mathrm{AD}$ has been associated with pathological severity $(11,12,17-19)$. However, in some studies, it has been reported that there is an unchanged level of IR protein $(20,21)$.

Insulin activity in the brain occurs via the Phosphatidylinositol3-kinase (PI3K)/Akt pathway and the Ras/Mitogen-Activated Protein Kinase (MAPK) pathway. In the PI3K pathway; binding of insulin to extracellular $\alpha$-subunits of IR induces dimerization of $\beta$-subunits that activate intrinsic tyrosine kinases and cause receptor autophosphorylation. The tyrosine kinase activity of IR phosphorylates tyrosine residues on IR Substrate 1 (IRS1) or IR Substrate 2 (IRS2). IRS1 and IRS2 bind to the p85 regulatory subunit of the PI3K complex. It provides the expression of phosphatidylinositol 3,4,5-triphosphate (PIP3) by phosphorylation of phosphatidylinositol 4,5-diphosphate (PIP2) $(11,22)$. PIP3 activates other enzymes in the cascade, including serine/threonine kinase Akt (protein kinase B) and protein kinase $\mathrm{C}$, by stimulating the phosphorylation of phosphoinosidedependent protein kinase 1 (PDK1) (23). AKT, which is associated with systemic glucose control, induces the translocation of Type 4 Glucose Transporter (GLUT-4) to the cell membrane, which is responsible for glucose uptake in muscle, fat and some neurons (11). GLUT-4, which moves to the cell surface, provides glucose entry into cells (24). It has been shown that this insulin signaling pathway is altered, and IRs are significantly reduced in the brain of individuals with $\mathrm{AD}$ (Figure 1) $(25,26)$.

Although most of the glucose uptake in neurons occurs via GLUT-3, studies have shown that GLUT-4, which is regulated by insulin activity, is co-expressed with GLUT-3 in rodent brain regions associated with cognitive behavior. These regions include the basal forebrain, hippocampus, amygdala, and to a lesser

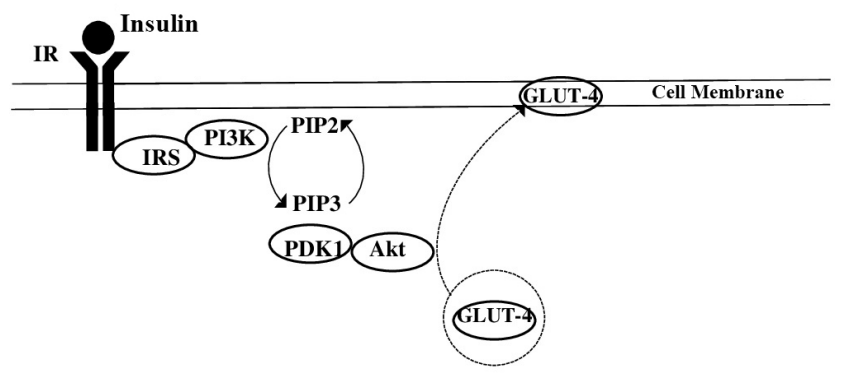

Figure 1. Insulin/PI3K/Akt pathway degree the cerebral cortex and cerebellum. Insulin activation is thought to not only induce the translocation of GLUT- 4 to the neuron cell membrane through an AKT-dependent mechanism, but also improve glucose flow to neurons during periods of high metabolic processes such as learning (11). However, it is known that insulin activity changes in both $\mathrm{AD}$ and T2DM (27).

Insulin binding to IRs can also initiate other intracellular signaling cascades. IR-mediated signal transduction is related to PI3K-dependent activation of protein kinase $\mathrm{B}$, which triggers phosphorylation of glycogen synthase (GS) kinase 3 (GSK-3) and stimulates the enzyme GS. As detected in the studies, the disorder in the phosphorylation of GSK-3 is associated with a number of neurological disorders, including AD. Studies show that the reduction of phosphorylated GSK-3 $\beta$ facilitates the formation of NFT, as it may cause hyperphosphorylation of tau $(10,26)$.

Insulin-like growth factor (IGF-1) has a critical importance for cell proliferation, coping with stress and survival in many cell types in the body. In the CNS, there is expression of IGF-1 receptor (IGF-1R) in neurons, glia cells and brain vessels, which indicates that they are critical effectors for IGF-1 signaling (28). Like insulin, IGF-1 is responsible for transmitting signals necessary for cellular survival and growth through IRS molecules. Decreased IRS expression levels are associated with resistance to GF in the CNS. Decreased IGF-1, IGF-1R and IRS gene expressions cause downregulation of the IRS-associated PI3 signaling pathway (with decreased levels of IRS-1 associated with p85), decreased levels of phospho-Akt (decreased Akt activity), and reduced levels of phospho-GSK3 $\beta$ (increased GSK-3 $\beta$ activity) (29). Results of a study on postmortem AD brains show that impaired IGF-1 mechanism leads to abnormalities in AD (17).

Various studies conducted to date have emphasized that insulin and IGF resistance in the brain cause inhibition of signaling pathways necessary for cell growth and survival mechanisms. Previous studies have shown that insulin improves neuronal survival by inhibiting apoptotic processes. This hormone may exert a neuroprotective effect by interfering with toxins and stressmediated apoptosis, and possibly via the PI3K/Akt pathway or the mTOR-p70S6K pathway (10).

Soluble $A \beta$ peptide oligomers are known to act synaptotoxicly. Since $A \beta$ and insulin are both amyloidogenic peptides that share a common sequence recognition motif, it is possible that both molecules can bind to IR. It is known that $A \beta$ binds to IRs in the hippocampus, inhibits the receptors, increases the neurodegenerative process in the region and causes significant cognitive losses. Given this assumption, $A \beta$ can increase insulin resistance through its antagonistic effect, block the IR downstream pathway, and facilitate the phosphorylation of GSK3, a taurelated molecule. Therefore, the aging process associated with insulin resistance, $A \beta$ production and tau hyperphosphorylation may lead to neuronal dysfunction (14). Despite all these findings, in a study on the relationship between $\mathrm{T} 2 \mathrm{DM}$ and $\mathrm{AD}$, amyloid accumulation was examined on 28 human brain samples with 
T2DM and 19 without T2DM, and it was reported that T2DM did not increase the frequency of amyloid formed in the brain. However, in the same study, it was stated that the amyloid size formed in patients with T2DM increased with the progression of the diabetes process (30).

While IR and IGF-1R are abundant in healthy human brains, it has been shown that both IRs and IGF-1Rs are significantly reduced in the brains of patients with $\mathrm{AD}$. In individuals with $\mathrm{AD}$, there is a decrease in insulin and IGF-1 levels in their brains and the cellular sensitivity of the brain to these factors due to impaired transport throughout the BBB. The obtained data highlight a gradual decrease in hypothalamic IR sensitivity, downstream signaling molecules such as (IRS-1), insulin and IGF receptor expression in patients with AD. Neuropathological findings suggest that brain insulin resistance and decreased IR function may be associated with memory problems. Additionally, studies have linked decreased gene expressions and protein levels of IGF-1R and other downstream signaling molecules with impaired acetylcholine production and impaired cognitive performance. Desensitation of neuronal IRs and low insulin concentrations in the CNS lead to a decrease in acetylcholine secretion and a consequent decrease in cerebral blood flow. These events cause chronic abnormalities in oxidative brain metabolism $(10,14,26,31)$.

In vitro experiments have shown that phosphorylation of tau, a marker of $\mathrm{AD}$, is normally regulated by insulin and IGF1. In a study, it was shown that serum IGF-1 levels in STZinduced diabetes model rats were decreased compared to the control group. Impaired insulin signaling can result in tau hyperphosphorylation. Likewise, there are studies showing that impaired IGF-1 signal may be responsible for this effect. These degradation processes can also cause cell death mediated by apoptosis, mitochondrial dysfunction or necrosis. These disruptions may also promote oxidative stress, which contributes to the neurodegeneration cascade and leads to behavioral and cognitive deficits associated with dementia $(10,27)$.

Impaired insulin function and IGF-1 signaling have been implicated as pathogenetic factors contributing to the onset of $\mathrm{AD}$. When all these data are taken together, it is thought that there may be common causes and mechanical connections in the underlying mechanisms of T2DM and $\mathrm{AD}$ (31).

\section{Insulin Degrading Enzyme (IDE)}

Although insulin is known to be a neurotrophic factor at moderate concentrations, its increased presence in the brain suggests that it may be associated with decreased $A \beta$ degradation. This effect may be related to their competition for binding to insulin degrading enzyme (IDE), which is the common excretion mechanism of $A \beta$ and insulin.

The IDE is a $\mathrm{Zn}^{+2}$ metalloprotease that catabolizes both insulin and $A \beta$ and can critically interfere with $A \beta$ degradation.

When the insulin-PI3K-Akt signaling pathway is activated, besides promoting the brain's glucose uptake, this signaling pathway activation stimulates the production of IDE to lower the insulin level. If this mechanism is disrupted, IDE is downregulated.

Since insulin controls IDE expression and intracellular A $\beta$ formation, decreased insulin amount in the brain may increase intraneuronal $A \beta$ accumulation. $A \beta$ can compete directly with insulin for binding to IDE. Therefore, in the case of hyperinsulinemia, $A \beta$ cannot be eliminated by IDE due to competitive binding of insulin and $A \beta$ to IDE, and then A $\beta$ accumulates. A study has shown that immunomodulatory agents (IL-6, C-reactive protein, tumor necrosis factor- $\alpha$ $($ TNF- $\alpha)$ ) involved in inflammatory states are associated with decreased IDE levels. In conclusion, studies emphasize that there may be abnormal $A \beta$ accumulation in diabetes due to impaired insulin signaling, which causes decreased IDE levels $(9,10,32)$.

Despite all these data, the evidence for the relationship between T2DM and molecular or pathologically defined neurodegenerative diseases in humans is mostly negative. Only one study in the literature found that systemic insulin resistance was associated with $A \beta$ positivity in the brain on PET imaging (33). However, other studies showed increased total tau and phospho-tau levels in patients with T2DM, but did not find a relationship between T2DM and A $\beta$ PET findings or CSF A $\beta$ levels (34).

\section{Hyperglycemia, Inflammatory Response and $A \beta$}

According to a 6-year cohort study, high blood glucose levels increase the risk of developing dementia in both people with and without diabetes (35). Constantly high blood glucose in diabetes causes an imbalance in the formation and destruction of reactive oxygen species (ROS), accumulation of excessive advanced glycation end products (AGEs), and disruption of intracellular messenger pathway signals (10).

The AGEs are formed from glucose by irreversible and nonenzymatic reactions. Production of AGEs is accelerated due to the increased formation of reactive oxygen species in diabetic patients (32). In an immunohistochemical postmortem study on brain samples from patients with diabetes, $\mathrm{AD}$ and both, it was reported that patients with $\mathrm{AD}$ with $\mathrm{T} 2 \mathrm{DM}$ had higher levels of AGEs and microglial activation in the CNS compared to patients with $\mathrm{AD}$ without T2DM (36).

In addition, increased AGE formation causes excessive ROS formation. In vitro findings show that ROS production caused by AGEs stimulates APP-related signaling pathways, leading to $A \beta$ formation and accumulation $(10,37)$. In $A D, A G E$ immunoreactivity is increased especially in $A \beta$ plaques and hippocampal neurons. Therefore, it is thought that oxidative damage may have an early effect in the development of $\mathrm{AD}$ (32). The high level of AGE immunoreactivity found in senile plaques and NFTs confirms that AGEs cause amyloidosis (A $\beta$ deposition) and NFT formation. Accumulated AGEs bind to their receptors (RAGE). RAGEs belong to the immunoglobulin superfamily, which can be located in various cell domains, and they can recognize and bind to various ligands. RAGEs found in brain 
endothelium, microglia, and neurons may also act as receptors for $A \beta$ and mediate $A \beta$-related microglia activation, resulting in the inflammatory response in $\mathrm{AD}$. Furthermore, excessive RAGE expression in microglia was found to increase the production of interleukin- 6 (IL-6) and TNF- $\alpha$ and accumulation of $A \beta$ in ADassociated brain regions in mutant APP/RAGE rodents (Figure 2). AGEs binding to RAGEs induce sustained upregulation of the NFKB transcription factor. As a result, NFKB signal triggers the accumulation of $A \beta$ in the brain in $\operatorname{AD}(9,10)$. In a study conducted on 92 brain samples, it was observed that dementia was associated with more $A \beta$ accumulation and free radical damage in nondiabetic patients with dementia, while dementia in diabetic patients was reported to occur mostly with activation of neuroinflammation and microvascular infarcts (38). In conclusion, in the light of the above-mentioned data, it can be concluded that the persistently high blood glucose levels and inflammation in the diabetes process affect AD-related pathologies through various mechanisms.Amyloid Precursor Protein (APP) and Beta Secretase 1 Enzyme (BACE-1)

The $A \beta$ peptide load and cerebral plaques in the neocortical terminal areas of the brain are important pathological features of $\mathrm{AD}$ (4). The $\mathrm{A} \beta$ peptide contains $36-43$ amino acids and is formed as a result of sequential proteolysis of APP under normal physiological conditions (39).

The APP is an integral membrane glycoprotein of which physiological role has not been fully elucidated. However, APP is known to affect neurite outgrowth and synaptic plasticity.

The APP is degraded by the enzymes $\alpha$-secretase, $\beta$-secretase (BACE-1) and $\gamma$-secretase, and a protein complex that includes presenilin 1 (PS1). While cleavage of APP by $\alpha$ secretase results in soluble peptides; its cleavage by $\beta$ and $\gamma$ secretases in neuropathological conditions leads to amyloidogenic metabolism and accumulation of $A \beta$. While $A \beta$ degradation enzyme 1 ( $\beta$-secretase) (BACE-1) cuts APP at its $\mathrm{N}$-terminal end, $\gamma$-secretases cut it at its $\mathrm{C}$-terminal end and fragments of 40 and 42 amino acids $A \beta 40$ and $A \beta 42$ are formed extracellularly (Figure 3).

BACE-1 is also known as the rate-limiting enzyme in the production of $A \beta$ through degradation of APP in AD. Animal studies indicate that insulin deficiency can alter APPrelated processes to promote $\beta$-amyloidogenesis via BACE-1 translational upregulation. Recent data from animal studies have demonstrated that neuronal expression of human BACE1 induces systemic diabetes complications through stimulation of hypothalamic dysfunction, insulin resistance, and glucose changes. In an experiment using PLB4 mice, it was shown that the risk of diabetes increased when BACE-1 was overexpressed in neurons, and that there was a complex mechanical interaction between T2DM and AD $(10,14)$.

\section{Glycogen Synthase Kinase-3 (GSK-3) and Tau Hyperphosphorylation}

The GSK-3 $\beta$ is a protein kinase that is phosphorylating GS and is inactivated by phosphorylation. Although its specific and precise mechanism is still unclear, recent studies suggest that the insulin signaling pathway-related GSK- $3 \beta$ may be a potential link between AD and T2DM (22).

The insulin-activated PI3K/Akt signaling pathway also plays a role in the physiological function of the hippocampus, which is severely affected in $\mathrm{AD}$, apart from the direct modulation of glucose uptake (10). Studies have shown that insulin increases cell survival by stimulating cell proliferation and inhibiting the apoptosis process through the PI3K/Akt/GSK-3 $\beta$ signaling pathway. Studies show that dysfunction of the PI3K/Akt/GSK$3 \beta$ signaling pathway leads to excessive phosphorylation of tau by increasing GSK-3 $\beta$ activity. High expression of GSK-3 $\beta$ has been associated with decreased insulin sensitivity, decreased blood sugar regulation and insulin deficiency.

The islet $\beta$-cells are endocrine cells in the body that secrete insulin and lower blood sugar levels. GSK-3 $\beta$ is also one of the key factors mediating $\beta$ islet cell apoptosis. In diabetic mice, overactivation of GSK-3 $\beta$ has been shown to result in decreased $\beta$ islet cell proliferation, and studies have closely linked GSK- $3 \beta$ with insulin deficiency. When there are insulin deficiency and IGF-1 signal dysfunction, GSK-3 $\beta$ inhibition is prevented by inhibition of PI3K/Akt activity, and therefore the regulation of blood sugar is impaired. Under diabetic conditions, the increase in oxidative stress leads to activation of the C-Jun- $\mathrm{N}$ terminal kinase (JNK) pathway, resulting in increased phosphorylation of GSK-3 $\beta$. GSK-3 $\beta$ hyperactivity also has anti-proliferative and pro-apoptotic effects on the body. Studies have shown

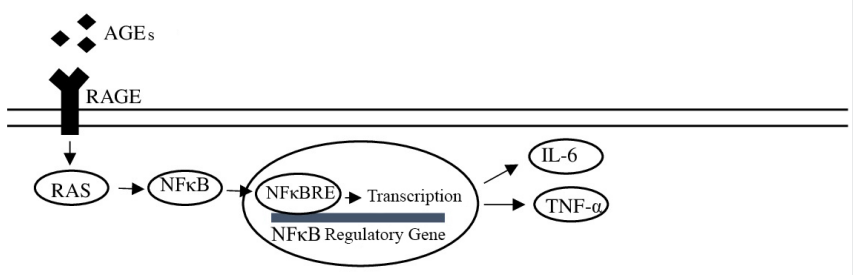

Figure 2. Schematic representation of the inflammatory response

AGE: Advanced glycation end products, RAGE: AGE receptors, NFkB : Nuclear Factor kappa B, NFkBRE: Nuclear Factor kappa B response element, IL-6: interleukin-6, TNF-a: tumor necrosis factor-a

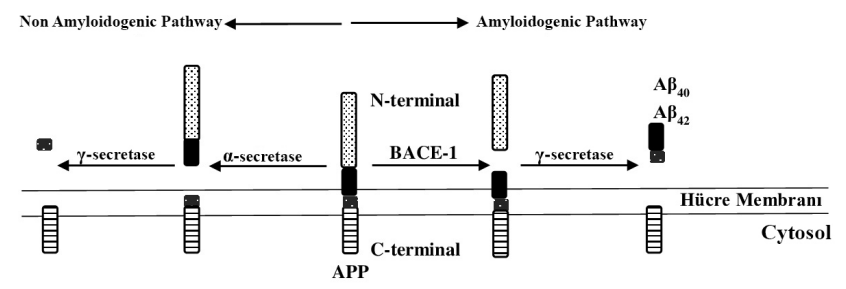

Figure 3. Schematic representation of metabolic pathways of amyloid precursor protein 
that PI3K/Akt/GSK-3 $\beta$ pathway disorders result in tau hyperphosphorylation $(9,22)$.

Again in diabetic animal models, AD-like pathoanatomical features such as decreased learning ability have been observed in animals as a result of down-regulation of Akt and GSK$3 \beta$ phosphorylation. In addition, in vitro experiments have shown that activated GSK-3 $\alpha$ in neurons triggers APP-related $\gamma$-secretase activity and thus increases $A \beta$ production (10).

\section{Apolipoprotein E (APOE)}

It is known that the Apolipoprotein E (APOE) genotype affects peripheral glucose and insulin metabolism. The $\varepsilon 4$ allele of the APOE gene has been associated as a risk factor for AD. Diabetic patients carrying the $\varepsilon 4$ allele of the APOE gene have a higher risk of developing $\mathrm{AD}$ than non-diabetic volunteers who also carry the $\varepsilon 4$ allele. This information is understood as a result of the understanding that patients with $\mathrm{AD}$ who do not carry the apolipoprotein $\varepsilon 4$ alleles have a better response to intranasal insulin than those who do.

In addition, as in other diseases, gender has an effect on the tendency and incidence of pathology. APOE-positive carrier women are at higher risk than men in terms of developing sporadic $\mathrm{AD}$ and giving less favorable response to insulinrelated treatments $(14,25,40)$. However, studies paying attention to the APOE genotype in patients with T2DM have also reported that the extent of $\mathrm{AD}$ pathology is higher in patients with T2DM who carry the $\varepsilon 4$ allele of the APOE gene compared to those who do not $(41,42)$. Moreover, recent findings have reported that APOE4 causes worsening of impaired insulin signaling by interacting with IR and disrupting the exchange mechanisms between endosomes and plasma membranes (14).

Along with all these studies, Starks et al. (43) stated that they found a positive relationship with tau measurements in apolipoprotein $\mathrm{E}(\mathrm{APOE}) \varepsilon 4$ positive individuals, but that they also did not find a direct relationship between systemic insulin resistance and CSF A $\beta$, total tau or phospho-tau levels (19).

\section{Investigation of the Effects of Drugs Used in the Treatment of Diabetes on Alzheimer's Disease}

Studies on intranasal insulin administration have reported that it has significant effects on cognition and neurophysiology (11).

Data from previous preclinical studies suggest that intranasal administration of insulin or insulin analogs provides some degree of improvement in memory or protection against cognitive impairment in $\mathrm{AD}$ mouse models. In a recent study, it was reported that intranasal insulin administration improved memory at a certain level in patients with mild cognitive impairment or $\operatorname{AD}(14,37)$.

Studies have shown that acute and chronic intranasal insulin administrations improve memory and other cognitive functions in adults with T2DM. Improvement in memory functions was observed with intranasal insulin administration in patients with $\mathrm{AD}$, but this improvement was reported only for patients without APOE $\varepsilon 4$ allele $(11,40)$.

In addition to treatment with insulin, drugs that are commonly used in T2DM, acting by increasing insulin sensitivity, have recently attracted attention as potential treatments for brain insulin resistance in AD-like dementias. The use of GLP-1 agonists in AD mouse models reduced the levels of pathological markers of $A D$, including oligomeric $A \beta$ and $A \beta$ plaque burden, and the amount of microglial activation, and improved memory-related behaviors. The GLP-1 analogs can reverse tau hyperphosphorylation induced by AGEs, and the main mechanism here is thought to be downregulation of GSK-3 $\beta$ (32,37). Many in vivo and in vitro studies have reported that GLP-1 receptor agonists are neuroprotective in experimental models of AD (44). In an animal study, GLP1 was shown to protect neurons from oxidative stress, reduce apoptosis, inflammatory response and plaque formation, and maintain synaptic plasticity in the brain. Sitagliptin (DPP4 inh) treatment in a mouse model of AD increased brain GLP1 levels, reduced brain nitrosative stress and inflammation, and prevented memory impairment associated with $A \beta$ accumulation (25).

The DPP-4 inhibitors have been shown to reduce GSK-3 $\beta$ activity by increasing GSK-3 $\beta$ Ser9 phosphorylation. In this way, it is possible to inhibit $A \beta$-induced neuronal cell apoptosis and subsequently the impairment in insulin signaling induced by $A \beta$ ameliorates and tau hyperphosphorylation decreases. Researchers have shown that the use of Metformin, the most commonly prescribed drug for T2DM, in patients with mild cognitive impairment (MCI) or early dementia due to $\mathrm{AD}$ produces some signs of benefit. In addition, thiazolidinedione-based nuclear peroxisome proliferator activated receptor- $\gamma$ (PPAR $\gamma$ ) agonists, originally developed to increase insulin sensitivity in T2DM, have demonstrated numerous beneficial neuronal effects in animal models of neurodegenerative diseases. Drugs targeting glucagon-like peptide-1 (GLP 1) have shown promising results in $\mathrm{AD}$ in preclinical and early clinical studies $(11,37)$. Impairment in spatial learning, tau hyperphosphorylation, and neuroinflammation were improved in $3 x \mathrm{Tg}-\mathrm{AD}$ mice treated with Pioglitazone for 4 months (14).

Systemic administration of Liraglutide for 8 weeks in AD transgenic mice was shown to prevent memory impairment, neuronal loss, and impaired synaptic plasticity in the hippocampus. The GLP-1 receptor agonists, Liraglutide and Exenatide, were found to antagonize processes associated with neurodegeneration and AD's progression, even in mouse models without diabetes. It was shown that litaglutide could reduce amyloid plaque accumulation by $40-50 \%$ and reduce the active microglial cell inflammatory response. Exenatide, another GLP-1 analogue, was also shown promising results in use for neurodegenerative diseases in preclinical studies (32).

In Table 1, clinical studies on the effects of some drugs used in diabetes on $\mathrm{AD}$ or mild cognitive disorders are summarized (45). 
Table 1. Phase studies investigating the effects of drugs used in the treatment of diabetes on Alzheimer's disease.

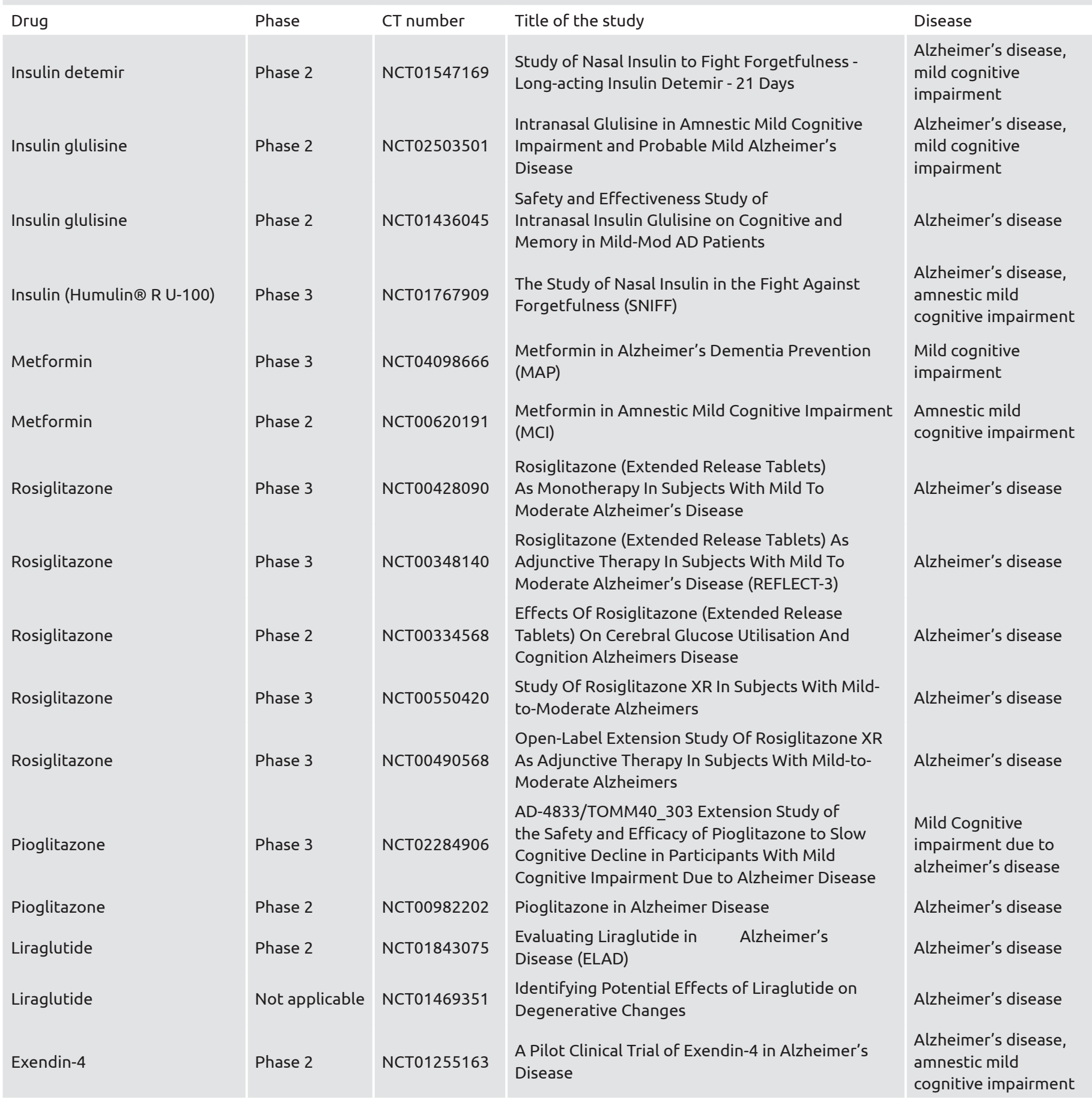

\section{Discussion}

There appear to be studies highlighting convincing evidence that patients with diabetes have an increased risk of developing $\mathrm{AD}$. However, it can be said that there are few detailed epidemiological data for risk factors. In addition, understanding which of the possible mechanisms are clinically significant with studies explaining the pathophysiological features of these two diseases will provide a better understanding of the relationship between these two diseases.

Peer-review: Externally peer reviewed.

\section{Authorship Contributions}

Data Collection or Processing: RD., S.P., Analysis or Interpretation: F.B., Literature Search: R.D., S.P., Writing: F.B., R.D., S.P.

Conflict of Interest: No conflict of interest was declared by the authors.

Financial Disclosure: The authors declared that this study received no financial support. 


\section{References}

1. Haan MN. Therapy Insight: type 2 diabetes mellitus and the risk of late-onset Alzheimer's disease. Nature clinical practice Neurology 2006;2:159-66.

2. Kolarova M, García-Sierra F, Bartos A, Ricny J,Ripova D. Structure and pathology of tau protein in Alzheimer disease. Int J Alzheimers Dis 2012;2012:1-13.

3. Striepens N, Scheef L, Wind A, Popp J, Spottke A, Cooper-Mahkorn $\mathrm{D}$, et al. Volume loss of the medial temporal lobe structures in subjective memory impairment. Dement Geriatr Cogn Disord 2010;29:75-81.

4. Querfurth HW, LaFerla FM. Mechanisms of disease. N Engl J Med 2010;362:329-44.

5. Hoyer $S$. The brain insulin signal transduction system and sporadic (type II) Alzheimer disease: an update. J Neural Transm 2002;109:341-60.

6. Laws SM, Hone E, Gandy S,Martins RN. Expanding the association between the APOE gene and the risk of Alzheimer's disease: possible roles for APOE promoter polymorphisms and alterations in APOE transcription. J Neurochem 2003;84:1215-36.

7. ME EEV,DERNEĞİ A. TANI ve TEDAVİ KILAVUZU.

8. Aguiree F, Brown A, Cho NH, Dahlquist G, Dodd S, Dunning T, et al. IDF DIABETES ATLAS. 2013.

9. Chatterjee S, Mudher A. Alzheimer's disease and type 2 diabetes: A critical assessment of the shared pathological traits. Front Neurosci 2018;12:383.

10. Nday CM, Eleftheriadou D, Jackson G. Shared pathological pathways of Alzheimer's disease with specific comorbidities: current perspectives and interventions. J Neurochem 2018;144:360-89.

11. Arnold SE, Arvanitakis Z, Macauley-Rambach SL, Koenig AM, Wang H-Y, Ahima RS, et al. Brain insulin resistance in type 2 diabetes and Alzheimer disease: concepts and conundrums. Nat Rev Neurol 2018;14:168.

12. Erbaş O. Is Alzheimer's disease, type 3 diabetes? D J Med Sci 2015;1:48-51.

13. McLean FH, Grant C, Morris AC, Horgan GW, Polanski AJ, Allan $\mathrm{K}$, et al. Rapid and reversible impairment of episodic memory by a high-fat diet in mice. Sci Rep 2018;8:1-9.

14. Folch J, Ettcheto M, Busquets O, Sánchez-López E, Castro-Torres $\mathrm{RD}$, Verdaguer E, et al. The implication of the brain insulin receptor in late onset Alzheimer's disease dementia. Pharmaceuticals (Basel) 2018;11:11.

15. De la Monte SM,Wands JR. Alzheimer's disease is type 3 diabetesevidence reviewed. J Diabetes Sci Technol 2008;2:1101-13.

16. Devaskar SU, Giddings SJ, Rajakumar PA, Carnaghi LR, Menon RK, Zahm DS. Insulin gene expression and insulin synthesis in mammalian neuronal cells. J Biol Chem 1994;269:8445-54.

17. Steen E, Terry BM, J Rivera E, Cannon JL, Neely TR, Tavares R, et al. Impaired insulin and insulin-like growth factor expression and signaling mechanisms in Alzheimer's disease--is this type 3 diabetes? J Alzheimers Dis 2005;7:63-80.
18. Cholerton B, Baker LD, Craft S. Insulin, cognition, and dementia. Eur J Pharmacol 2013;719:170-9.

19. Rivera EJ, Goldin A, Fulmer N, Tavares R, Wands JR, de la Monte $\mathrm{SM}$. Insulin and insulin-like growth factor expression and function deteriorate with progression of Alzheimer's disease: link to brain reductions in acetylcholine. J Alzheimers Dis 2005;8:247-68.

20. Talbot K, Wang H-Y, Kazi H, Han L-Y, Bakshi KP, Stucky A, et al. Demonstrated brain insulin resistance in Alzheimer's disease patients is associated with IGF-1 resistance, IRS-1 dysregulation, and cognitive decline. J Clin Invest 2012;122:1316-38.

21. Moloney AM, Griffin RJ, Timmons S, O'Connor R, Ravid R, O'Neill C. Defects in IGF-1 receptor, insulin receptor and IRS-1/2 in Alzheimer's disease indicate possible resistance to IGF-1 and insulin signalling. Neurobiol Aging 2010;31:224-43.

22. Zhang Y, Huang N-q, Yan F, Jin H, Zhou S-y, Shi J-s, et al. Diabetes mellitus and Alzheimer's disease: GSK-3 $\beta$ as a potential link. Behav Brain Res 2018;339:57-65.

23. Plum L, Belgardt BF, Brüning JC. Central insulin action in energy and glucose homeostasis. J Clin Invest 2006;116:1761-6.

24. McNay EC, Pearson-Leary J. GluT4: A central player in hippocampal memory and brain insulin resistance. Exp Neurol 2020;323:113076.

25. Zhong KL, Chen F, Hong H, Ke X, Lv YG, Tang SS, et al. New views and possibilities of antidiabetic drugs in treating and/or preventing mild cognitive impairment and Alzheimer's disease. Metab Brain Dis 2018;33:1009-18.

26. Zhang J, Chen C, Hua S, Liao H, Wang M, Xiong Y, ve ark. An updated meta-analysis of cohort studies: diabetes and risk of Alzheimer's disease. Diabetes Res Clini Pract 2017;124:41-7.

27. Isik AT, Celik T, Ulusoy G, Ongoru O, Elibol B, Doruk H, et al. Curcumin ameliorates impaired insulin/IGF signalling and memory deficit in a streptozotocin-treated rat model. Age (Dordr) 2009;31:39-49.

28. Ashpole NM, Sanders JE, Hodges EL, Yan H,Sonntag WE. Growth hormone, insulin-like growth factor-1 and the aging brain. Exp Gerontol 2015;68:76-81.

29. Rickle A, Bogdanovic N, Volkman I, Winblad B, Ravid R,Cowburn RF. Akt activity in Alzheimer's disease and other neurodegenerative disorders. Neuroreport 2004;15:955-9.

30. Janson J, Laedtke T, Parisi JE, O’Brien P, Petersen RC,Butler PC. Increased risk of type 2 diabetes in Alzheimer disease. Diabetes 2004;53:474-81.

31. Li Z-g, Zhang W, Sima AA. Alzheimer-like changes in rat models of spontaneous diabetes. Diabetes 2007;56:1817-24.

32. Simsir IY, Soyaltin UE,Cetinkalp S. Glucagon like peptide-1 (GLP1) likes Alzheimer's disease. Diabetes Metab Syndr 2018;12:469-75.

33. Willette AA, Johnson SC, Birdsill AC, Sager MA, Christian B, Baker $\mathrm{LD}$, et al. Insulin resistance predicts brain amyloid deposition in late middle-aged adults. Alzheimers Dement 2015;11:504-10.e1.

34. Moran C, Beare R, Phan TG, Bruce DG, Callisaya ML,Srikanth V. Type 2 diabetes mellitus and biomarkers of neurodegeneration. Neurology 2015;85:1123-30. 
35. Crane PK, Walker R, Hubbard RA, Li G, Nathan DM, Zheng H, et al. Glucose levels and risk of dementia. N Engl J Med 2013;369:540-8.

36. Valente T, Gella A, Fernàndez-Busquets X, Unzeta M, Durany N. Immunohistochemical analysis of human brain suggests pathological synergism of Alzheimer's disease and diabetes mellitus. Neurobiol Dis 2010;37:67-76.

37. Angelopoulou E, Piperi C. DPP-4 inhibitors: a promising therapeutic approach against Alzheimer's disease. Ann Transl Med 2018;6:255.

38. Sonnen JA, Larson EB, Brickell K, Crane PK, Woltjer R, Montine TJ, et al. Different patterns of cerebral injury in dementia with or without diabetes. Arch Neurol 2009;66:315-22.

39. Baglietto-Vargas D, Shi J, Yaeger DM, Ager R, LaFerla FM. Diabetes and Alzheimer's disease crosstalk. Neurosci Biobehav Rev 2016;64:272-87.

40. Avgerinos KI, Kalaitzidis G, Malli A, Kalaitzoglou D, Myserlis PG,Lioutas V-A. Intranasal insulin in Alzheimer's dementia or mild cognitive impairment: a systematic review. J Neurol 2018;265:1497-510.
41. Peila R, Rodriguez BL, Launer LJ. Type 2 diabetes, APOE gene, and the risk for dementia and related pathologies: The Honolulu-Asia Aging Study. Diabetes 2002;51:1256-62.

42. Malek-Ahmadi M, Beach T, Obradov A, Sue L, Belden C, Davis $\mathrm{K}$, ve ark. Type 2 diabetes is associated with increased Alzheimer's disease neuropathology in ApoE $\varepsilon 4$ Carriers. Curr Alzheimer Res 2013;10:654-9.

43. Starks EJ, Patrick O’Grady J, Hoscheidt SM, Racine AM, Carlsson $\mathrm{CM}$, Zetterberg H, et al. Insulin Resistance is Associated with Higher Cerebrospinal Fluid Tau Levels in Asymptomatic APOE 84 Carriers. J Alzheimers Dis 2015;46:525-33.

44. BatistaAF, Bodart-Santos V, DeFeliceFG, FerreiraST. Neuroprotective actions of glucagon-like peptide-1 (GLP-1) analogues in Alzheimer's and Parkinson's diseases. CNS Drugs 2019;33:209-23.

45. www.clinicaltrials.gov Af. Retrieved 25.04.2020 